\title{
Gains to Merging Firms and their Rivals: Evidence from Canada
}

Jean-Yves Filbien $^{a}$

\author{
Maher Kooli ${ }^{b}$
}

\author{
January 5, 2011
}

\begin{abstract}
We examine the wealth creation for acquiring and target firms' shareholders to Canadian merger and acquisition announcements. We also investigate the potential determinants of the stock market reactions. Further, we explore the impact of these announcements on the gains of the target firms' rivals. Takeovers are beneficial to the shareholders of merging firms. However, we show that Canadian rival firms lose abnormal returns.
\end{abstract}

JEL Classification: G34

EFM Classification: 160

Keywords: Merger, Performance, Event-Study

${ }^{a}$ Jean-Yves Filbien (corresponding author), Louvain School of Management \& FUCaM and Univ. Lille Nord de France - LSMRC - ECCCS, 151 Chaussée de Binche, 7000 Mons (Belgium), +32(0)-65323-447, e-mail: jean_yves.filbien@fucam.ac.be., ${ }^{b}$ Maher Kooli is full professor of finance, Université du Québec à Montréal (UQAM), School of Management, Department of finance, C.P. 6192, Succursale Centre-Ville, Montreal (Québec), Canada, H3C 4R2, Tel: 514 987-3000, ext. 2082, Fax: (514) 9870422, e-mail: kooli.maher@uqam.ca 


\section{Introduction}

An extensive literature analyzes the value creation process related to M\&A, as well as the factors that drive it. This literature also focuses on the ability of stock markets to fully and rapidly interpret the consequences of major transactions such as M\&As when these transactions are announced. It underlines that the target shareholders earn significant positive abnormal returns, whereas the evidence on the value creation of acquiring firms is mixed (Jensen and Ruback, 1983; Fuller et al., 2002; Moeller et al., 2004).

Several studies attempt to analyze the effect of M\&A on competitors (Eckbo, 1983; Stillman, 1983; Akhigbe and Martin, 2000; Song and Walkling, 2000; Fee and Thomas, 2004). They suggest that abnormal returns to rivals at the M\&A announcements correspond to a reaction to change in the industry. Our study contributes to this strand of M\&A literature by considering not only the stock market reaction of the acquirers and targets, but also the impact of the M\&A transaction on the industry competitors. Indeed, the spillover effects of $\mathrm{M} \& \mathrm{~A}$ announcement have important implications for various agents including investors, acquirers, targets, and industry competitors. Specifically, it is important for investors to know how M\&A announcements affect market prices. Acquirers are also concerned about the prices that they should pay for M\&As and know how these major transactions may impact their future corporate performance. Similarly, targets should understand the sources of value creation or destruction arising from M\&A. Finally, rivals need to understand how M\&A announcements affect their competitive environment and how they can strategically respond to them. To illustrate the M\&A's effect on the rivals, we consider the example of the Microsoft Corp.'s attempt to acquire Yahoo Inc. Indeed, on February 1, 2000, the Wall Street Journal reported that Microsoft Corp. was offering $\$ 44.6$ billion in an attempt to acquire Yahoo Inc. The market reacted differently for both firms, the Microsoft Corp's shares fell down almost $7 \%$ on the announcement date, $1 \%$ and $4 \%$ in the next two days while those of Yahoo Inc. rose of $47 \%$. Alongside, the shares of Google, a competitor of Yahoo Inc., also fell down almost $9 \%$.

This paper has three goals. First, we investigate the short term price reaction of M\&A announcements for acquiring and target firms. Second, we also explore the potential determinants of the stock market reactions. Third, we analyze the spillover effects of these announcements on the acquiring and target firms' competitors.

We contribute to M\&A literature in several ways. First, we consider an outof-sample investigation of the short-term M\&A performance, using Canadian data. Canada is a well-developed country, with an intensive M\&A market. However, it differs from the U.S. one giving the concentration of minerals and financials industries. Furthermore, the Canadian antitrust rules are less constrained and extended for merging firms, while the anti-takeover laws are less developed in Canada. To get a broader 
picture, we also consider both Canadian and U.S. targets. This research is one of the few studies available that examine Canadian cross-border acquisitions. Second, we include in our sample the M\&A wave of the late 1990s and 2000s, the most significant ever, both in terms of numbers and value, and the recent financial crisis period, which represents an interesting framework to examine. Third, we examine potential determinants of the short-term price reaction.

Consistent with the literature, our results suggest that M\&A announcements result in a wealth creation for acquiring and target firms' shareholders. Furthermore, the M\&A announcement affects positively the abnormal returns of the U.S. target firms' rivals. Conversely, the acquiring firms' competitors are influenced negatively by information.

The rest of this article is organized as follows: In Section 2, we present a review of the literature and develop the hypotheses for our empirical tests. We describe the data and method in Section 3. In Section 4, we discuss the empirical results. In Section 5, we conclude.

\section{Background and Hypotheses Development}

\subsection{Short-term Price Reactions}

Empirical studies find returns close to zero or even negative around the M\&A announcements for U.S. firms that acquire public targets (Jensen and Ruback, 1983; Mulherin and Boone, 2000; Andrade et al., 2001; Fuller et al., 2002), while Canadian bidders earn positive average announcement period abnormal returns. Eckbo and Thorburn (2000) consider a Canadian sample of 1,846 acquisitions over the period 1964-1983 and find that domestic bidders earn significantly positive average announcement period abnormal returns. The literature on the Canadian M\&A market argues that the gains experienced by acquiring firms are due to the weakness of anti-takeover regulations. Yuce and Ng (2005), using a Canadian sample of M\&A between 1994 and 2000, find that the acquiring company shareholders earn significant and positive abnormal returns for a two-day holding period starting with the announcement day. Ben-Amar and André (2006) find that the announcement period abnormal returns for Canadian acquiring firms are positive over the 1998-2000 period and that the positive abnormal returns are greater for family controlled firms. Dutta and Jog (2009), using a sample of 989 acquiring firms, also find significant and positive cumulative abnormal returns around the announcement date (1.6\% over a six-day period surrounding the announcement).

Hypothesis 1.a: We expect a positive market reaction for public bidding firms around M\&A announcements. 
Target shareholders earn significantly positive abnormal returns from acquisitions. Using a sample of 332 targets listed on the TSE, Eckbo and Thorburn (2000) calculate cumulative abnormal returns of $3.59 \%$ during the announcement month. Yuce and $\mathrm{Ng}$ (2005) also find a wealth creation for target firms' shareholders. They calculate cumulative abnormal returns of $7.69 \%$ over a five-day period around the announcement.

Hypothesis 1.b: We expect a positive market reaction for public target firms around MESA announcements.

\subsection{Short-term Price Reactions of Rivals}

We analyze the theoretical and empirical studies on the stock market reactions of rival firms to M\&A announcements (Eckbo, 1983; Stillman, 1983; Eckbo and Wier, 1985; Aktas et al., 2004). The expected impact of M\&A announcements on rival firms' returns is positive.

\subsubsection{Market Power Hypothesis or Collusion Hypothesis}

The coordination of the companies' actions is a natural process, with the aim of collectively and individually increasing their profits. This coordination could be related to either a reduction in production and/or an increase in price, defining a tacit or an explicit collusion agreement among the competitors. M\&As also trigger a reduction in costs for the new entity. The collusion hypothesis suggests that the horizontal mergers facilitate the collusion with the remaining companies. The reduction of competition will increase the market power and thus the expected cash flows, benefiting to the merging and rival firms. Henceforth, companies involved in the collusion benefit from monopoly rents and will collect positive abnormal returns at the merger announcement (Eckbo, 1983). Furthermore, the creation of wealth could be bigger for rivals because they are not obliged to reduce on their production to respect the collusion. The shareholders of the rival firms will benefit from the merger by adopting a free rider strategy. Indeed, Stigler (1950) argues that if the industry is concentrated, then it is more profitable to be an outsider and sells at the same industry price but and has a much larger output. Salant et al. (1983) also find that the increase in production by rivals will reduce insider profits. However, even if companies have interest to reduce the production, they also have an incentive to diverge. This diverting behavior leads firms to also increase their production.

Using a sample of 259 horizontal and vertical mergers over a 1963-1978 period, Eckbo (1983) tests the collusion hypothesis. He also examines the wealth creation for bidding, target, and rivals shareholders at the announcement of antitrust complaint. 
Eckbo finds that the rivals of the 65 horizontal challenged mergers have positive abnormal returns at the merger proposal announcement. While the subsequent information about the antitrust complaint triggers negative abnormal returns for merging firms, Eckbo observes that the rivals gain positive abnormal returns. These results are not consistent with the collusion hypothesis. Eckbo and Wier (1985) examine 82 horizontal challenged mergers between 1963 and 1981. Around a probability-decreasing event, Eckbo and Wier find no evidence of significant abnormal returns for rivals, although these events destroy value for the merging firms' shareholders. Eckbo and Wier conclude that their results are inconsistent with the collusion hypothesis. Using a sample of 192 targets involved in terminated mergers over a 1987-1996 period, Akhigbe et al. (2000) find that rivals gain significatively an average of $0.28 \%$ over the three-day M\&A announcements windows. Theirs results are inconsistent with the market power.

The literature on market power underlines several characteristics of industry or company related to the existence of collusion. These determinants are linked to the emergence of collusion or its survival. Firms collude only if (i) they expect an increase in price and could maintain a high price; (ii) the possible incurred penalties are lower than the expected gains; (iii) the setting up is lower than expected gains. Several factors influence a low cost of setting up: concentration (Hay and Kelley, 1974; Slade, 1989), fewness of competitors numbers (Hay and Kelley, 1974), product homogeneity (Hay and Kelley, 1974), variability in demand (Spence, 1978), atomicity of demand request (Spence, 1978), business conditions (Haltiwanger and Harrington, 1991), and barriers to entry and to exit (Glais, 1993).

Hypothesis 2.a: Under the market power hypothesis, we expect a positive market reaction for public bidding and target firms' rivals around MEA announcements.

\subsubsection{Signaling Hypothesis}

M\&A announcements could contain information about a process innovation or a technological innovation which makes the cost-efficiencies possible (Jarrell and Bradley, 1980; Chatterjee, 1986). M\&A announcement could represent a signal regarding to innovation or productivity that can also be exploited by rival firms regardless of whether they are involved in a merger. Thus, competitors' stock prices could increase at an M\&A announcement if the stock market deduces that rivals could realize efficiency gains through future mergers. Recently, studies investigate how M\&A announcements convey information about the increase in the rivals' likelihood to be targeted (Akhigbe et al., 2000; Song and Walkling, 2000). Using a sample of 192 targets involved in terminated mergers over a 1987-1996 period, Akhigbe et al. (2000) find that the termination of the merger results in significant negative returns for targets, but rivals experience significant positive returns because the termination signals an increase in the proba- 
bility that rival firms will become acquisition targets. Their results are thus consistent with the signaling effect hypothesis. Moreover, Song and Walkling (2000) consider an acquisition probability model and find that the rivals of target firms earn abnormal returns and that the probability for rivals to be targets themselves increases. Specifically, using a sample of 141 acquisition announcements containing 2.459 rivals, over a 1982-1991 period, the authors find that the abnormal returns to rivals are $0.56 \%$ with $63.1 \%$ of positive values. Moreover, they find that the abnormal returns to rival firms tend to increase with the magnitude of surprise about an acquisition. Previous studies observe that concentration ownership affects the probability to be targeted (Walkling, 1985; Shleifer and Vishny, 1986; Mikkelson and Partch, 1989; Song and Walkling, 1993; Goldman and Qian, 2005).

Hypothesis 2.c: Under the signaling hypothesis, we expect a positive market reaction for public bidding and target firms' rivals around MEA announcements.

\subsection{Main Potential Determinants of Short-term Price Reac- tions}

M\&A announcements affect the wealth creation for merging firms' shareholders. In this section, we describe the determinants affecting the wealth creation to M\&A announcements for target, acquiring, and rival firms.

\subsubsection{Acquiring firm size}

Previous studies find that the size of the bidding firms affect their performance (Schwert, 2000). Large acquiring firms cumulate lower abnormal returns. Using a sample of more than 12,000 deals announced between 1980 and 2001, Moeller et al. (2004) examine the cumulative abnormal returns of acquiring firms according to their size. Moeller et al. show that firm size negatively affects the short run performance of acquiring firms whatever the target status. The authors also find that shareholders of bidding firms gain $1.10 \%$ on a three-day event period, with large firms do not have significant abnormal returns whereas small firms create value. Moreover, they present that in terms of dollars, the cumulative abnormal returns are -25.2 millions of dollars. They thus suggest that the value destruction, underlined by the literature, is only valid for large acquiring firms. Furthermore, studies observe that relative size between the acquiring and target firms is positively related to short-term performance of bidding firms (Asquith et al., 1983; Jarrell and Poulsen, 1989; Servaes, 1991).

Hypothesis 3.a: We expect a positive market reaction for small bidding firms around MEA A announcements. 


\subsubsection{Target Status}

Prior literature indicates that low liquidity of private target firms reduce their acquisition price (Fuller et al., 2002; Moeller et al., 2004). Previous studies observe small positive abnormal returns for the bidding firms when they acquire a public target firm (Chang, 1998; Hansen and Lott, 1996; Fuller et al., 2002; Moeller et al., 2004). BenAmar and André (2006) confirm this result on the Canadian M\&A market. They find a $2.10 \%$ gain for bidding firms' shareholders when they acquire private target firms, whereas they lose when they buy a public target firm. Faccio et al. (2006) also confirm this result by controlling for the ownership structure.

Hypothesis 3.b: We expect a positive market reaction for bidding firms around MEA A announcements implying private target firms.

\subsubsection{Form of Payment}

The payment of the deal can take different forms, such as cash, stocks, or a mixed of both. The choice of the payment's method could send a signal to the stock market on the acquiring firms' value. A stock payment could reflect an overvaluation of acquiring firms' stock prices and drive stock markets to react negatively. Furthermore, managers of acquiring firms, possessing privileged information on the true value of their firm will choose the most appropriate form of payment. The literature has analyzed the impact of the payment form on the cumulative abnormal returns for acquiring firms (Myers and Majluf, 1984; Travlos, 1987) and target firms (Huang and Walkling, 1987). Using a sample of 167 mergers and acquisitions, from 1972 to 1981, Travlos (1987) finds that the abnormal returns of acquiring firms are smaller for stock deals $(-1.6 \%)$ than cash deals (-0.13\%). This result is consistent with Amihud et al. (1990); Brown and Ryngaert (1991); Servaes (1991); Andrade et al. (2001); Moeller et al. (2004). In Canada, Ben-Amar and André (2006) find that cash transactions outperform other types of transactions. However, Hansen (1987) suggests that the acquiring firms should pay their transactions by stock when the information asymmetry with the target firms is high to share the operational risk. Recently, Officer et al. (2009) confirm this observation.

Hypothesis 3.c: We expect a positive market reaction for bidding firms around MEA announcements for cash deals.

\subsubsection{Other Determinants}

Deal Form Potential buyers could choose to either negotiate with the managers of the target or to make a tender offer to shareholders. Public takeover bids do not require 
approval by the board of the target and are therefore quicker. The offer implies a price superior to the market price. Moeller et al. (2004) indicate that the bidding firms experience more gains with a tender offer.

Hostility A target that receives a takeover bid can either accept the transaction or reject it aggressively. If the target firm rejects it aggressively, the deal is characterized as hostile. A hostile reaction is intended to prevent the acquisition or initiate negotiation for a better offer (Schwert, 2000). Schwert (2000) suggests that the hostile deals decrease the probability of success of the transaction. Nonetheless, Schwert concludes that a manifestation of hostility seems to be mainly linked to strategic negotiation. Since the end of the 1980s, the number of hostile deals has been reduced. Using a sample of transactions, from 1975 to 1996, and five definition of hostility, Schwert (2000) finds that the hostile deals have small abnormal returns. However, Moeller et al. (2004) do not find significative evidence of the relationship between hostility and abnormal returns around the acquisition announcements.

Competition Competition is frequent in M\&As market (Schwert, 2000; Bange and Mazzeo, 2004). Prior literature analyzed competition among potential acquirers and its effects on the acquisition value creation (Bradley et al., 1988; Servaes, 1991; Schwert, 1996; Fuller et al., 2002). Bradley et al. (1988) find that the wealth transfer from bidding firms' shareholders to those of target firms decreases with the number of buyers. Using a sample of 236 transactions from 1963 to 1984, Bradley et al. observe that the acquiring firms' cumulative abnormal returns are $-1.45 \%$ for deals with competition and $0.65 \%$ for non competitive deals, on a three-day event window. Regarding target firms, the authors also find cumulative abnormal returns of $22.01 \%$ with multiple buyers and only $20.74 \%$ with only one bidder. Bradley et al. explain this result by the reduction of the attractive characteristics of target firms. This result is consistent with Servaes (1991). Examining 704 acquisitions over the 1972-1987 period, Servaes finds that the abnormal returns of target firms increase when there are multiple potential acquirers with a gain of $30.53 \%$ (20.83\% for single buyer deal), although they are smaller for acquiring firms with a loss of $2.97 \%$ (-0.35\% for single buyer deal).

Relatedness The literature indicates that relatedness creates more value (Ravenscraft and Scherer, 1987; Kohers and Kohers, 2000). The merging firms save cash when they exploit the same market. However, empirical results find no evidence for acquiring firms (Morck et al., 1990 in U.S., Ben-Amar and André, 2006 in Canada).

Cross-Border Deal The theory of corporate multinationalism predicts an increase in the firm's market value from the expansion of its existing multinational network (Doukas and Travlos, 1988). Moreover, in a cross-border deal, the merging firm could 
exploit market imperfections in outside markets (Eun et al., 1996). Using a sample of 383 cross-border deals and 4,046 domestic transactions, Moeller and Schlingeman (2005) find evidence of underperforming cross-border M\&As. From a sample of 327 acquiring firms, Ben-Amar and André (2006) indicate that the cross-border deals have a significant positive impact on abnormal returns. However, integration costs and cultural issues qualify these gains. Eckbo and Thorburn (2000) also find that Canadian acquirers do better than U.S. acquirers.

\section{Data and Method}

\subsection{Data}

Our sample comes from the Securities Data Company's (SDC) database. We select public Canadian acquiring firms with announcement dates between January 1, 1994 and December 31, 2009. We require that (1) the transaction is completed, (2) the deal value is greater than $\$ 5$ million, (3) the target firm's nation is Canada or UnitedStates. Our final sample contains 1748 acquisitions announcements. In Table 1, we present the top 10 transactions in our sample. We observe that six deals are crossborder and imply U.S. firms. These operations justify the inclusion of U.S. target firms into our sample. Moreover, the biggest deal was announced on March 23, 2009, when Suncor Energy Inc. and Petro-Canada, two oil Canadian firms, proposed to create the country's largest energy company.

In Figure 1, we plot the number of acquisitions and the total dollar value of transactions by year. We notice a positive trend in M\&A activity during the event period. However, we observe two slowdowns in 2001 (the dot.com bubble) and in 2008 (the financial crisis). The M\&A activity is consistent with the overall M\&A market as highlighted by Bauguess and Stegemoller (2008); Kau et al. (2008).

In Table 2, we report the summary statistics according to the characteristics of the deal, acquiring, and target firms of our 1748 acquisitions sample. We find 299 (17.10\%) cash payments, 589 stock payments (33.69\%), and 860 (49.19\%) mixed payments. The breakdown between friendly and hostile transactions is consistent with prior studies. Only 34 (1.94\%) transactions are classified by the SDC as being hostile or neutral, while $1714(98.06 \%)$ are classified as friendly. We observe 298 (17.04\%) tender offers. 790 $(45.19 \%)$ of all transactions are between firms with the same primary SIC codes (4 Digit code). Regarding the bidding firms' characteristics and as expected, $46.51 \%$ of the 1748 transactions in Canada are in the resource industries. The rest of the transactions are distributed across several industries. Regarding the target firms' characteristics, 389 $(22.25 \%)$ involve a U.S. target firms. We also note 854 (48.85\%) transactions implying a public target firm. Moreover, we create three categories of deal size: Less than $\$ 10$ millions, between $\$ 10$ millions and $\$ 100$ millions, and more than $\$ 100$ millions. Half of 
Figure 1: Number of Transactions and Dollar Value of Transactions (in Millions of U.S. dollars)

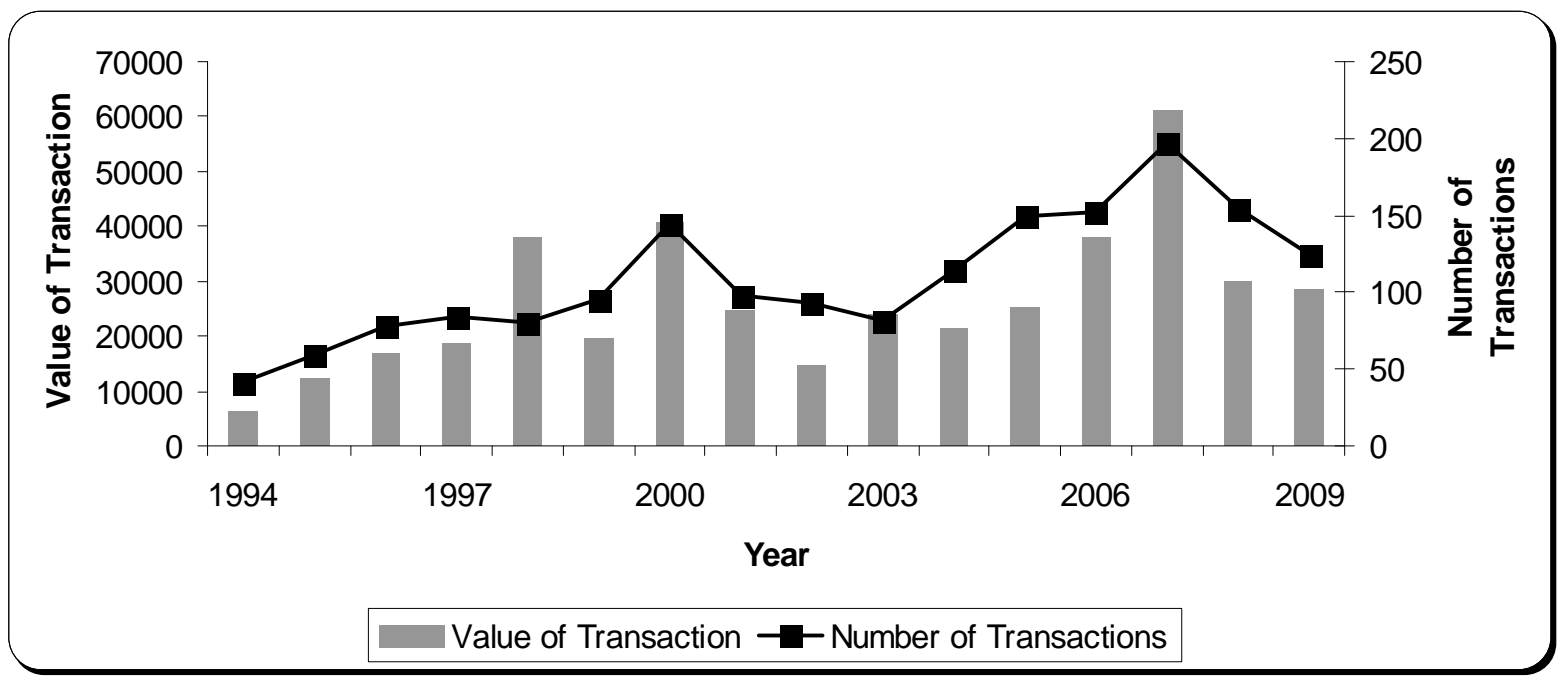

Table 1: Descriptive Statistics of Top Deals

We present the top deals between January 1, 1994, and December 31, 2009 from a sample of 1748 completed including a public Canadian acquiring firm.

\begin{tabular}{|c|c|c|c|c|c|}
\hline $\begin{array}{l}\text { Date } \\
\text { Announced }\end{array}$ & $\begin{array}{l}\text { Date } \\
\text { Effective }\end{array}$ & $\begin{array}{l}\text { Acquirer } \\
\text { Name }\end{array}$ & Target Name & $\begin{array}{l}\text { Target } \\
\text { Nation }\end{array}$ & $\begin{array}{l}\text { Value of } \\
\text { Deal (mil. } \\
\text { US \$) }\end{array}$ \\
\hline $23 / 03 / 2009$ & $03 / 08 / 2009$ & Suncor Energy Inc & Petro-Canada & Canada & 15,582 \\
\hline $29 / 07 / 2008$ & $30 / 10 / 2008$ & Teck Cominco Ltd & Fording Canadian Coal Trust & Canada & 13,599 \\
\hline $28 / 09 / 2003$ & $28 / 04 / 2004$ & Manulife Financial Corp. & John Hancock Finl Sves Inc & U.S. & 11,063 \\
\hline $31 / 10 / 2005$ & $15 / 03 / 2006$ & Barrick Gold Corp. & Placer Dome Inc & Canada & 10,209 \\
\hline $15 / 06 / 1998$ & $31 / 08 / 1998$ & Northern Telecom Ltd & Bay Networks Inc & U.S. & 9,269 \\
\hline $31 / 08 / 2006$ & $04 / 11 / 2006$ & Goldcorp Inc & Glamis Gold Ltd & U.S. & 8,670 \\
\hline $02 / 10 / 2007$ & $31 / 03 / 2008$ & Toronto-Dominion Bank & Commerce Bancorp, NJ & U.S. & 8,638 \\
\hline $28 / 07 / 2000$ & $05 / 10 / 2000$ & Nortel Networks Corp. & Alteon Websystems Inc & U.S. & 7,057 \\
\hline $15 / 06 / 1998$ & $10 / 11 / 1998$ & Teleglobe Inc & Excel Communications Inc & U.S. & 6,407 \\
\hline $27 / 01 / 2002$ & $05 / 04 / 2002$ & PanCanadian Energy Corp. & Alberta Energy Co Ltd & Canada & 6,097 \\
\hline
\end{tabular}


transactions concern deals between $\$ 10$ millions and $\$ 100$ millions (909). Finally, we also associate acquiring firms according to its size. We define small acquiring firms in a given year to be firms whose capitalization is below the $25^{\text {th }}$ percentile of TSX firms that year, medium acquiring firms in a given year to be firms whose capitalization is between the $25^{\text {th }}$ and the $75^{\text {th }}$ percentile of TSX firms that year, and large acquiring firms in a given year to be firms whose capitalization is above the $75^{\text {th }}$ percentile of TSX firms that year. The distribution of the sample shows that half of acquirers are small companies. ${ }^{1}$

\footnotetext{
${ }^{1}$ We lose data due to their unavailability.
} 


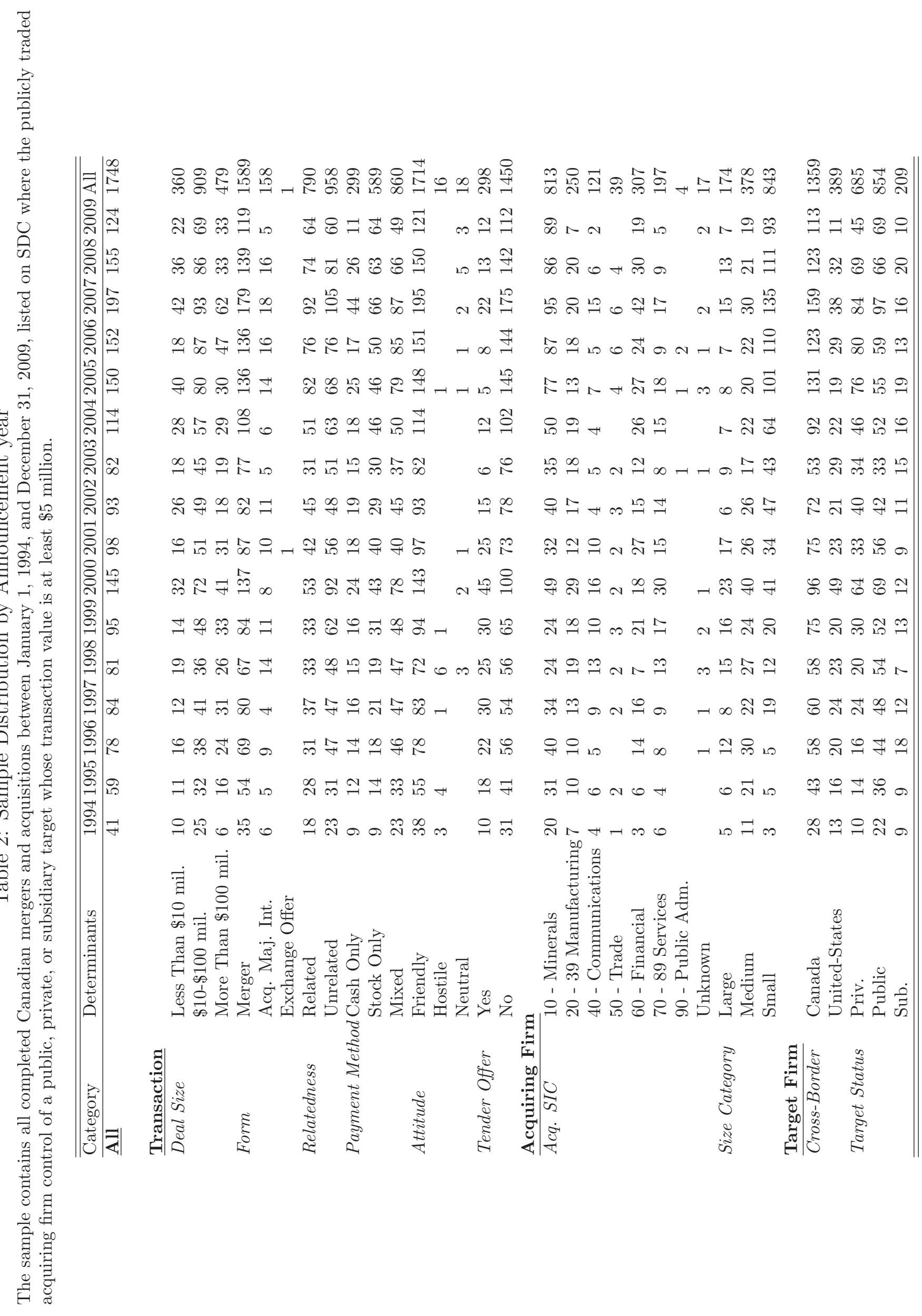




\subsection{Method}

\subsubsection{Event Study Methodology}

We calculate the abnormal returns using the event study methodology introduced by Fama et al. (1969). Abnormal returns can be estimated with three different models: the constant mean returns model, the market model, or the adjusted return risk market model. The measure of abnormal returns is robust to the choice of model (Brown and Warner, 1985). We estimate these abnormal returns over the three-day event window using market model benchmark returns with the S\&P TSX60 index returns for Canadian firms and the CRSP value-weighted index returns for U.S. firms:

$$
A R_{i, t}=R_{i, t}-\left(\alpha_{i}+\beta_{i} R_{m, t}\right)
$$

where $R_{i, t}$ indicates the return of stock $\mathrm{i}$ at time $\mathrm{t}, R_{m, t}$ is the market return at time $\mathrm{t}$, and $\mathrm{t}=0$ is the announcement date. We calculate the returns as follows: $R_{i, t}=\ln \left(\frac{P_{i, t}}{P_{i, t-1}}\right)$, where $P_{i, t}$ is the price of stock $\mathrm{i}$ on day t. Following Brown and Warner (1985), we estimate the coefficients $\alpha$ and $\beta$ of stock i over the period from 300 days to 15 days before the acquisition announcement. Then, we estimate the cumulative abnormal returns for merging firms over the $\mathrm{T}$ trading days that surround the announcement dates [-T days; $+\mathrm{T}$ days]:

$$
C A R_{i}=\sum_{t=-T}^{T} A R_{i, t} .
$$

To test for statistical significance, we control for event-induced variance (Boehmer et al., 1991).

\subsubsection{Definition of Rivals}

To define a set of potential target competitors, we identify the industry classification of each firm, its size, and its market-to-book ratio. We define a rival as a company which is in the same industry and in the same size and market-to-book category.

Industry We classify firms according to their industry. For Canadian firms, we use the sector definition classified by Datastream. We consider a Canadian firm as a rival if one firm is in the same sector as the target firms. For U.S. firms, we use the SIC code (Akhigbe and Martin, 2000; Fee and Thomas, 2004). We prefer to use SIC code from CRSP than SDC due to matching issues (Kahle and Walkling, 1996), and it allows to take into account time-series variation in industry classification. 
Size We adjust our definition of rivals using firm size. We calculate the annual quartiles of market capitalization into the industry. We consider a firm as a rival if one firm is in the same quartile category as the merging firms.

Market-to-Book Further, we adjust our definition of rivals using the market-tobook ratio. We calculate the annual quartiles of the market-to-book into the industry. We exclude individual outliers for market-to-book ratio where market-to-book is superior to 0.10 in absolute value (Baker and Wurgler, 2002). We consider a firm as a rival if one firm is in the same quartile category as the merging firms.

In Table 3, we present the descriptive statistics for the sample of rivals. We also provide the results according to industry. In Table 3 Panel A, we show the descriptive statistics for Canadian rivals. In Table 3 Panel B, we indicate the descriptive statistics for U.S. competitors.

We present the cumulative abnormal returns after grouping the rivals of each target firm into a value-weighted portfolio in which the weights are based on the market value at the announcement month. Then, we weigh each portfolio by the market value of the merging firm (either the acquiring firm for the acquirers' rivals or the target firm for the targets' rivals) to consider its size. 


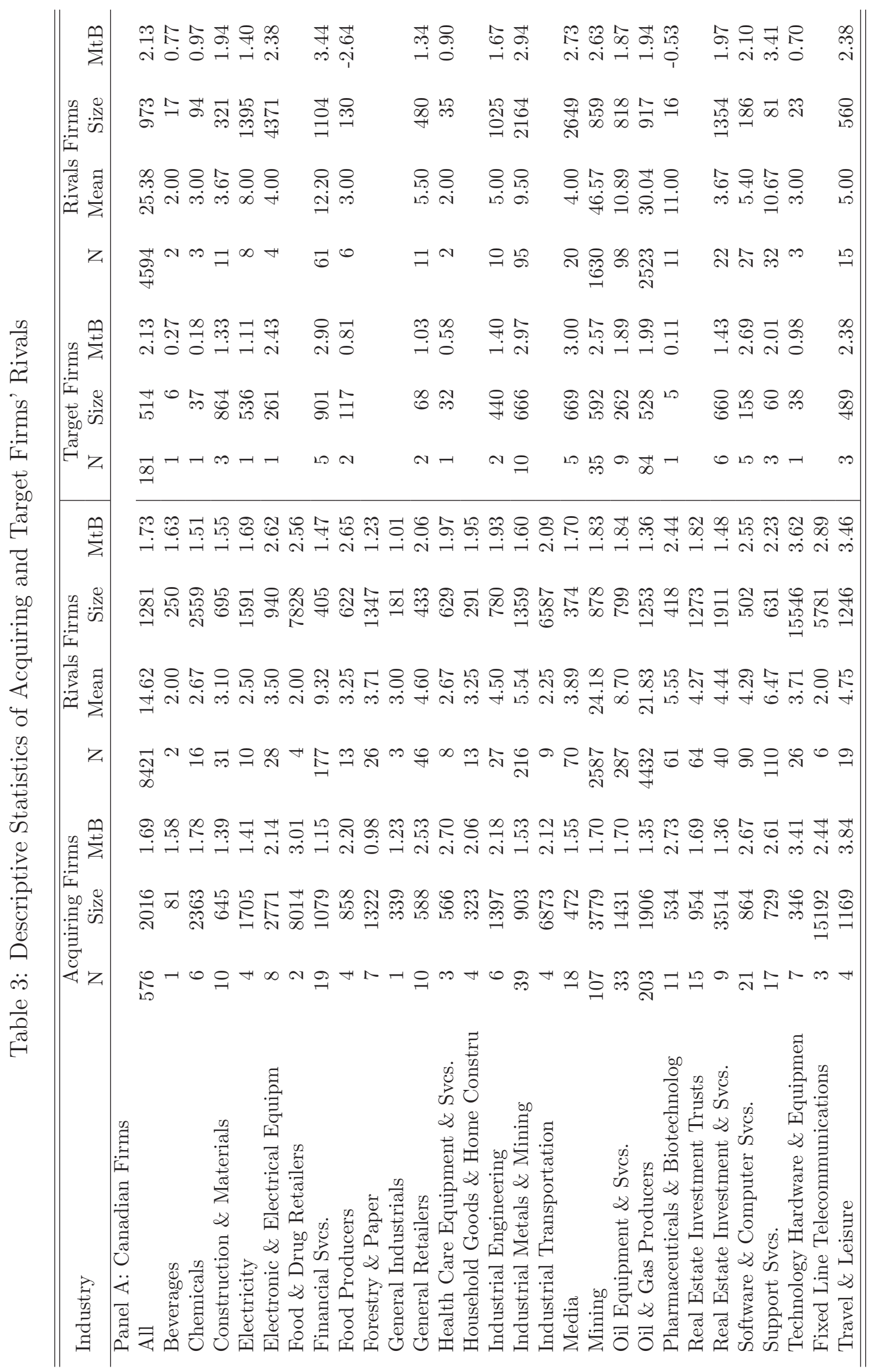




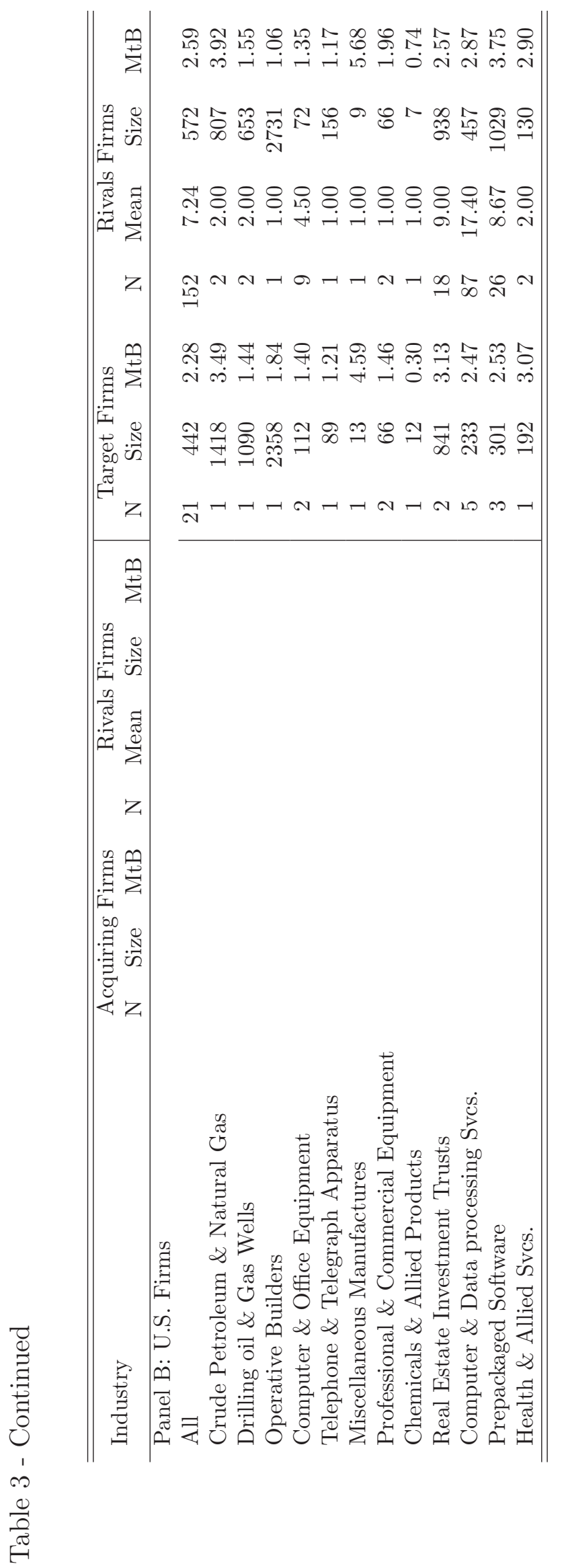




\section{Empirical Results}

\subsection{Cumulative Abnormal Returns to Acquiring and Target Firms}

In Table 4, we present the stock market reaction to M\&A announcement for acquiring and target firms (Canadian and U.S.) over several event periods.

In Panel A of Table 4, we observe positive cumulative abnormal returns for acquiring firms, regardless of the event window. Specifically, we find positive and significant cumulative abnormal returns of $2.45 \%$, over a three-day period surrounding the announcement. Consistent with previous studies, we confirm Hypothesis 1.a. However, we should say that it diverges from U.S. evidence in which the acquiring firms experience wealth destruction. The Canadian regulation and the absence of strict antitakeover rules could explain these differences in results. To test the impact of outliers, we exclude the first and the last percentile of the cumulative abnormal returns distribution. We observe that even if the cumulative abnormal returns are reduced, they are still positive and significant. To address the cross-sectional dependence problem induced by overlapping observations, we compare the cumulative abnormal returns of the first deal to those of overlapped subsequent transactions. If acquisitions occur within the current year of a previously included acquisition by the same firm, we class them in "More Than One Deal" category, "First Deal" otherwise. We observe that the majority of the wealth creation is concentrated in the first deal, whereas the following transactions do not imply positive and significant cumulative abnormal returns. Fuller et al. (2002) and Aktas et al. (2009) also find that the M\&A second bid announcements convey less information about the bidding firm than the first bid.

In Panel B of Table 4, we present the results for Canadian target firms. Consistent with the literature, the results indicate a wealth creation for shareholders. The cumulative abnormal returns are $14.22 \%$ over a three-day event period and are larger than for bidding firms. These results hold for different event windows and even after controlling for extremes values.

In Panel C of Table 4, we provide the stock market reaction for U.S. targets acquired by Canadian bidding firms. The results are similar to those of Canadian target firms. The cumulative abnormal returns are $15.21 \%$ and statistically significant surrounding a five-day period. We confirm Hypothesis 1.b. To test the robustness of this result, we examine different sizes for the event period. We also find positive and significant cumulative abnormal returns of $15.03 \%$ for the five days around the announcement. We also perform a sensitivity test on the outliers by eliminating values situated beyond the $1^{s} t$ and $99^{t} h$ percentiles and observe positive results of $15.68 \%$ (from an event window defined as the trading days $[-5,+5]$ around the announcement). 
Table 4: Cumulative Abnormal Returns

The sample contains all completed Canadian mergers and acquisitions between January 1, 1994, and December 31, 2009, listed on SDC where the publicly traded acquiring firm gains control of a public, private, or subsidiary target whose transaction value is at least $\$ 5$ million. CAR provides the cumulative abnormal returns (in percent) measured using the market model (S\&P TSX60 for Canadian firms and CRSP Value-Weighted for U.S. firms).

\begin{tabular}{|c|c|c|c|c|c|c|c|c|}
\hline & \multicolumn{2}{|c|}{ All } & \multicolumn{2}{|c|}{ Without Outliers } & \multicolumn{2}{|c|}{ First Deal } & \multicolumn{2}{|c|}{ More Than One Deal } \\
\hline & $\mathrm{N}$ & CAR & $\mathrm{N}$ & CAR & $\mathrm{N}$ & CAR & $\mathrm{N}$ & CAR \\
\hline \multicolumn{9}{|c|}{ Panel A: Acquiring Firms } \\
\hline $\operatorname{CAR}(0 ; 0)$ & 1353 & 0.27 & 1327 & 0.13 & 874 & $0.79^{* * *}$ & 479 & $-0.68^{* * *}$ \\
\hline $\operatorname{CAR}(-1 ;+1)$ & 1376 & $1.67^{* * *}$ & 1350 & $1.02^{* * *}$ & 885 & $2.83^{* * *}$ & 491 & $-0.42^{*}$ \\
\hline $\operatorname{CAR}(-2 ;+2)$ & 1376 & $2.55^{* * *}$ & 1350 & $1.71^{* * *}$ & 885 & $4.06^{* * *}$ & 491 & -0.18 \\
\hline $\operatorname{CAR}(-3 ;+3)$ & 1376 & $2.45^{* * *}$ & 1350 & $1.57^{* * *}$ & 885 & $4.01^{* * *}$ & 491 & -0.37 \\
\hline $\operatorname{CAR}(-5 ;+5)$ & 1377 & $2.77^{* * *}$ & 1351 & $2.01^{* * *}$ & 886 & $4.04^{* * *}$ & 491 & 0.49 \\
\hline $\operatorname{CAR}(-10 ;+10)$ & 1377 & $1.93^{* *}$ & 1351 & $1.38^{*}$ & 886 & $3.23^{* * *}$ & 491 & -0.41 \\
\hline \multicolumn{9}{|c|}{ Panel B: Canadian Target Firms } \\
\hline $\operatorname{CAR}(0 ; 0)$ & 508 & $9.88^{* * *}$ & 498 & $9.60^{* * *}$ & & & & \\
\hline $\operatorname{CAR}(-1 ;+1)$ & 522 & $12.92^{* * *}$ & 512 & $12.53^{* * *}$ & & & & \\
\hline $\operatorname{CAR}(-2 ;+2)$ & 522 & $13.91^{* * *}$ & 512 & $13.31^{* * *}$ & & & & \\
\hline $\operatorname{CAR}(-3 ;+3)$ & 522 & $14.22^{* * *}$ & 512 & $13.74^{* * *}$ & & & & \\
\hline $\operatorname{CAR}(-5 ;+5)$ & 522 & $15.56^{* * *}$ & 512 & $15.10^{* * *}$ & & & & \\
\hline $\operatorname{CAR}(-10 ;+10)$ & 523 & $16.61^{* * *}$ & 513 & $16.10^{* * *}$ & & & & \\
\hline \multicolumn{9}{|c|}{ Panel C: U.S. Target Firms } \\
\hline $\operatorname{CAR}(0 ; 0)$ & 91 & $9.72^{* * *}$ & 91 & $9.72^{* * *}$ & & & & \\
\hline CAR $(-1 ;+1)$ & 106 & $14.30^{* * *}$ & 104 & $14.52^{* * *}$ & & & & \\
\hline $\operatorname{CAR}(-2 ;+2)$ & 106 & $14.97^{* * *}$ & 104 & $15.03^{* * *}$ & & & & \\
\hline $\operatorname{CAR}(-3 ;+3)$ & 106 & $14.87^{* * *}$ & 104 & $15.06^{* * *}$ & & & & \\
\hline CAR $(-5 ;+5)$ & 106 & $15.21^{* * * *}$ & 104 & $15.68^{* * *}$ & & & & \\
\hline $\operatorname{CAR}(-10 ;+10)$ & 106 & $16.30^{* * *}$ & 104 & $16.78^{* * *}$ & & & & \\
\hline
\end{tabular}




\subsection{Cumulative Abnormal Returns to Merging Firms' Rivals}

In Table 5, we present the cumulative abnormal returns for acquiring and target firms' rivals estimated over the eleven trading days that surround the announcement dates [-5 days; +5 days]. The choice of this window of eleven trading days helps us control for possible news leaks. It also allows more time to investors to gather additional information (Song and Walkling, 2000). We also report the determinants of the cumulative abnormal returns. Further, we test the collusion impact on shareholders' gains. We expect that the most concentrated industries gain the highest cumulative abnormal returns. To proxy the industry concentration, we use the number of firms per industry. A concentrated sector corresponds to two or three firms contained in industry. Finally, we also define the surprise into industry estimating the first deal after a dormant period (Song and Walkling, 2000). We choose a dormant period of six months. We anticipate that the wealth creation is related to the degree of surprise in each industry. We will discuss results for acquiring, Canadian target, and U.S. target firms.

First, regarding buyers' rivals, we observe that they experience negative abnormal returns. The average cumulative abnormal returns of rivals' portfolios are $-0.55 \%$ (statstic-t $=-2.90)$. We do not valid Hypothesis 2.a. Among the determinants of this result, we also notice that shareholders mainly lose when (i) their rivals purchase private target firms $(-1.78 \%)$, (ii) the bid is paid with mixed payment $(-0.96 \%)$, and (iii) the deal value is less than 10 millions U.S. dollars (-1.43\%).

Second, the rivals of Canadian target firms also experience losses, which not support Hypothesis 2.b. We find negative cumulative abnormal returns and the wealth destruction is larger than for acquirers' rivals. We show that the cumulative abnormal returns are significantly negative $-0.98 \%$ for target firms' rivals (versus $-0.55 \%$ for those of acquiring firms). We indicate that the transaction value impacts negatively the short-term performance of rivals. Moreover, we provide that their cumulative abnormal returns decrease with the deal size, for example, we find that the cumulative abnormal returns are $-1.09 \%$ for large transactions and $0.85 \%$ for medium deals. Moreover, the largest average cumulative abnormal returns occur when the transaction is hostile: $1.09 \%$ versus $-0.96 \%$ (in friendly deals). Our results show no evidence of collusion effect. Indeed, more concentrated sectors destroy more value for rivals' shareholders.

We refer the competitive hypothesis to explain negative stock market reaction for rivals. Indeed, merging firms possess sufficient advantages to be more competitive than their competitor (Chatterjee, 1986; Akhigbe et al., 2000). A cost-efficient production allows the merging firms to sell the product at a lower price than can its rivals. If rival firms do not launch a similar process, they suffer from an economic efficiency disadvantage. Competitors thus experience a negative stock price reaction.

Third, contrary to Canadian merging firms, the results indicate wealth creation for rivals of U.S. target firms. This result supports Hypothesis 2.b. On average, U.S. 
rivals target firms earn $3.61 \%$. This positive impact of M\&A announcement increases with the relatedness of transactions and the deal size. Further, for tender bids, the cumulative abnormal returns are a statistically significant positive $4.95 \%$. Consistent with the signaling hypothesis, the cumulative abnormal returns to portfolios of rivals are $3.67 \%$ during the first deal announcement, whereas the result is not significant at the following events.

\subsection{Further Evidence by Industry}

In Table 6, we report the cumulative abnormal returns for rivals of merging firms according to industry. ${ }^{2}$ From Table 2, we show that most of the deals are in minerals, financials, and telecommunications, which is consistent with the Canadian economic structure. Focusing on these industries, we observe that they are more affected than the other industries. Specifically, we find that minerals industries experience wealth destruction. The average cumulative abnormal returns for rivals are $-1.47 \%$ in mining industry and $-1.51 \%$ in Industrial Metals \& Mining industry. Regarding the target firms, we observe a cross-sectional variation of competitors' abnormal returns. Indeed, on one hand, Construction \& Materials and Financial Services industries gain to M\&A announcements. On the other hand, the stock market mainly reacts negatively in minerals industries.

\subsection{Cumulative Abnormal Returns to Acquiring and Target Firms' Characteristics}

In Table 7, we provide the cumulative abnormal returns for acquiring and target firms' rivals according to the bidding, target, and deal characteristics. We find that small acquiring firms perform significantly better than large firms when they make an acquisition announcement. When we consider the impact of the transaction value in the bidding firms' gains, we find that size has an impact on cumulative abnormal returns of acquiring firms. As in Moeller et al. (2004), we find that small deals experience significant wealth creation for acquirers' shareholders. This result supports Hypothesis 3.a.. Moreover, we observe that bidding firms gain when buying a private target firm or subsidiary, while acquirers' shareholders lose when they purchase a public target firm (Hypothesis 3.b is confirmed). Fuller et al. (2002) note that the purchase of a private firm occurs in a relatively illiquid market, obtaining a discount price and higher returns. We also estimate the impact of the payment method on acquisition announcement returns. Consistent with previous literature, we observe positive cumulative abnormal returns for deals paid with cash (Hypothesis 3.c). Furthermore, we find that the wealth creation related to the target status is larger if the deal is paid with stock. Consistent

\footnotetext{
${ }^{2}$ We exclude of from our sample industries with less than two competitors.
} 
Table 5: Cumulative Abnormal Returns of Merging Firms' Rivals

The sample contains all completed Canadian mergers and acquisitions January 1, 1994, and December 31, 2009, listed on SDC where the publicly traded acquiring firm gains control of a public, private, or subsidiary target whose transaction value is at least $\$ 5$ million. We present the eleven-days cumulative abnormal returns (in percent) measured using the market model (S\&P TSX60 for Canadian firms and CRSP Value-Weighted for U.S. firms). We provide results after grouping the rivals of each target firm into a value-weighted portfolio.

\begin{tabular}{|c|c|c|c|}
\hline Determinants & $\begin{array}{l}\text { Acquiring Firms' } \\
\text { Rivals }\end{array}$ & $\begin{array}{l}\text { Can. Target Firms' } \\
\text { Rivals }\end{array}$ & $\begin{array}{l}\text { U.S. Target Firms' } \\
\text { Rivals }\end{array}$ \\
\hline All & $-0.55^{* *}$ & $-0.98^{* * *}$ & $3.61^{*}$ \\
\hline \multicolumn{4}{|l|}{ Acquirer Size } \\
\hline Small & -0.04 & & \\
\hline Medium & -0.17 & & \\
\hline Large & -0.69 & & \\
\hline \multicolumn{4}{|l|}{ Deal Size } \\
\hline Less Than $\$ 10$ mil. & $-1.43^{* *}$ & 8.88 & \\
\hline$\$ 10-\$ 100$ mil. & $-1.07^{* * *}$ & $0.85^{* * *}$ & $-1.04^{* *}$ \\
\hline $\begin{array}{l}\text { More Than } \$ 100 \text { mil. } \\
\text { Target Status }\end{array}$ & -0.37 & $-1.09^{* * *}$ & $5.38^{*}$ \\
\hline Priv. & $-1.78^{* * *}$ & & \\
\hline Public & $-0.51^{*}$ & $-0.98^{* * *}$ & $3.61^{*}$ \\
\hline Sub. & $0.51^{* *}$ & & \\
\hline \multicolumn{4}{|l|}{ Payment Method } \\
\hline Cash Only & 0.17 & -0.89 & 2.03 \\
\hline Mixed & $-0.96^{* * *}$ & -0.83 & $9.14^{*}$ \\
\hline Stock Only & -0.31 & $-1.09^{* * *}$ & 2.92 \\
\hline \multicolumn{4}{|c|}{ Target Status vs Payment Method } \\
\hline Cash Only Priv. & $0.34^{*}$ & & \\
\hline Cash Only Publi & 0.12 & -0.89 & 2.03 \\
\hline Cash Only Sub. & 0.56 & & \\
\hline Mixed Priv. & $-1.86^{* * *}$ & & \\
\hline Mixed Publi & $-1.24^{* * *}$ & -0.83 & $9.14^{*}$ \\
\hline Mixed Sub. & $0.56^{* *}$ & & \\
\hline Stock Only Priv. & $-8.35^{* * *}$ & & \\
\hline Stock Only Publi & 0.10 & $-1.09^{* * *}$ & 2.92 \\
\hline $\begin{array}{l}\text { Stock Only Sub. } \\
\text { Target Nation }\end{array}$ & -6.71 & & \\
\hline Canada & $-0.54^{* *}$ & $-0.98^{* * *}$ & \\
\hline United States & -0.55 & . & $3.61^{*}$ \\
\hline \multicolumn{4}{|l|}{ Form } \\
\hline Merger & $-0.49^{*}$ & $-0.97^{* * *}$ & $3.61^{*}$ \\
\hline Acq. Maj. Int. & -0.79 & $-1.30^{* *}$ & \\
\hline \multicolumn{4}{|l|}{ Related Acquisition } \\
\hline Related & $-0.78^{* *}$ & $-1.16^{* * *}$ & $7.38^{* * *}$ \\
\hline Unrelated & -0.23 & -0.55 & 1.44 \\
\hline \multicolumn{4}{|l|}{ Attitude } \\
\hline Friendly & $-0.76^{* * *}$ & $-0.96^{* * *}$ & $3.61^{*}$ \\
\hline Hostile & 2.86 & $1.09^{* * *}$ & \\
\hline Neutral & $1.90^{* *}$ & -2.30 & \\
\hline \multicolumn{4}{|l|}{ Tender Offer } \\
\hline Yes & 0.23 & -0.59 & $4.95^{* *}$ \\
\hline No & $-0.93^{* * *}$ & $-1.14^{* * *}$ & 3.05 \\
\hline
\end{tabular}


Table 5 - Continued

\begin{tabular}{lcll}
\hline \hline Determinants & $\begin{array}{l}\text { Acquiring Firms' } \\
\text { Rivals }\end{array}$ & $\begin{array}{l}\text { Can. Target Firms' } \\
\text { Rivals }\end{array}$ & $\begin{array}{l}\text { U.S. Target Firms' } \\
\text { Rivals }\end{array}$ \\
\hline $\begin{array}{l}\text { Surprise } \\
\text { First Deal }\end{array}$ & 0.05 & $-0.92^{* *}$ & $3.67^{*}$ \\
Beyond First Deal & $-0.64^{*}$ & $-1.01^{* * *}$ & -1.70 \\
Number of Firms in & & \\
{$[2-3]$} & -0.52 & -0.19 & 2.86 \\
More than 3 & -0.55 & $-0.98^{* * *}$ & 4.15 \\
\hline \hline
\end{tabular}

Table 6: Cumulative Abnormal Returns of Merging Firms' Rivals by Industry The sample contains all completed Canadian mergers and acquisitions between January 1, 1994, and December 31, 2009, listed on SDC where the publicly traded acquiring firm gains control of a public, private, or subsidiary target whose transaction value is at least $\$ 5$ million. We present the elevendays cumulative abnormal returns (in percent) measured using the market model (S\&P TSX60 for Canadian firms and CRSP Value-Weighted for U.S. firms). We provide results after grouping the rivals of each target firm into an equal-weighted portfolio.

\begin{tabular}{|c|c|c|}
\hline $\begin{array}{l}\text { Can. } \\
\text { Industry }\end{array}$ & $\begin{array}{l}\text { Acquiring } \\
\text { Firms' } \\
\text { Rivals }\end{array}$ & $\begin{array}{l}\text { Target } \\
\text { Firms' } \\
\text { Rivals }\end{array}$ \\
\hline \multicolumn{3}{|l|}{ Panel A: Canadian Firms } \\
\hline Chemicals & $6.05^{*}$ & \\
\hline Construction \& Materials & 0.61 & $4.76^{*}$ \\
\hline Electricity & 0.46 & \\
\hline Electronic \& Electrical Equipm. & $-7.27^{* *}$ & \\
\hline Food \& Drug Retailers & 2.17 & \\
\hline Financial Svcs. & 0.23 & $3.85^{* *}$ \\
\hline Food Producers & 1.52 & -1.09 \\
\hline Forestry \& Paper & -0.44 & \\
\hline General Retailers & $-2.23^{*}$ & $-2.38^{* *}$ \\
\hline Health Care Equipment \& Svcs. & -1.54 & \\
\hline Household Goods \& Home Constru. & 1.78 & \\
\hline Industrial Engineering & $1.81^{*}$ & -5.81 \\
\hline Industrial Metals \& Mining & $-1.51^{* * *}$ & -1.77 \\
\hline Industrial Transportation & -0.83 & \\
\hline Media & -0.23 & $-2.80^{* * *}$ \\
\hline Mining & $-1.47^{* * *}$ & $-1.95^{* * *}$ \\
\hline Oil Equipment \& Svcs. & -0.09 & $-5.78^{* * *}$ \\
\hline Oil \& Gas Producers & $0.67^{* * *}$ & $-0.68^{* *}$ \\
\hline Pharmaceuticals \& Biotechnology & -1.29 & \\
\hline Real Estate Investment Trusts & 0.47 & \\
\hline Real Estate Investment \& Svcs. & -0.53 & $-1.70^{* *}$ \\
\hline Software \& Computer Svcs. & -2.98 & $-3.00^{*}$ \\
\hline Support Svcs. & 0.06 & 0.42 \\
\hline Technology Hardware \& Equipm. & $-3.28^{* *}$ & \\
\hline Fixed Line Telecommunications & $-2.24^{*}$ & \\
\hline Travel \& Leisure & -1.79 & 0.52 \\
\hline \multicolumn{3}{|l|}{ Panel B: U.S. Firms } \\
\hline Computer \& Office Equipment & . & -0.98 \\
\hline Professional \& Commercial Equi. & . & -5.64 \\
\hline Real Estate Investment Trusts & . & -1.90 \\
\hline Computer \& Data Processing & . & 9.53 \\
\hline Prepackaged Software & . & 1.80 \\
\hline
\end{tabular}


with Fuller et al. (2002), our result shows that the cumulative abnormal returns are larger if the target is private and the deal paid in stock.

\section{Conclusion}

Examining a sample of Canadian acquisitions between 1994 and 2009, we study the wealth creation for acquiring and target firms' shareholders to Canadian M\&A announcements. We also investigate the potential determinants of the stock market reactions. Further, we explore the impact of these announcements on the gains of the acquiring and target firms' rivals.

The main results are as follows: First, we find wealth creation for both merging firms around the M\&A announcements. Second, we examine possible explanations for the performance of M\&A deals. Cash deals, acquisitions of private target firms, and transactions by small acquiring firms have a positive impact on value creation. Third, we find that Canadian rivals experience negative cumulative abnormal returns to M\&A announcements, while the U.S. rivals of U.S. targets benefit from this event.

Although we provide some explanations for the performance of rivals to M\&A announcements in Canada, the characteristics of the Canadian industry lead for further analysis. 
Table 7: Cumulative Abnormal Returns of Acquiring and Target Firms The sample contains all completed Canadian mergers and acquisitions between January 1, 1994, and December 31, 2009, listed on SDC where the publicly traded acquiring firm gains control of a public, private, or subsidiary target whose transaction value is at least $\$ 5$ million. CAR provides the elevendays cumulative abnormal percentage returns measured using the market model (S\&P TSX60 for Canadian firms and CRSP Value-Weighted for U.S firms.)

\begin{tabular}{|c|c|c|c|c|c|c|}
\hline \multirow{2}{*}{ Determinants } & \multicolumn{2}{|c|}{ Acquiring Firms } & \multicolumn{2}{|c|}{ Target Can. Firms } & \multicolumn{2}{|c|}{ Target U.S. Firms } \\
\hline & $\mathrm{N}$ & CAR & $\mathrm{N}$ & CAR & $\mathrm{N}$ & CAR \\
\hline All & 1377 & $2.77^{* * *}$ & 522 & $15.56^{* * *}$ & 106 & $15.21^{* * *}$ \\
\hline \multicolumn{7}{|l|}{ Acquirer Size } \\
\hline Small & 828 & $4.95^{* * *}$ & & & & \\
\hline Medium & 374 & -0.05 & & & & \\
\hline Large & 174 & -1.47 & & & & \\
\hline \multicolumn{7}{|l|}{ Deal Size } \\
\hline Less Than $\$ 10$ mil. & 274 & $6.86^{* * *}$ & 53 & $25.03^{* * *}$ & 4 & 1.25 \\
\hline$\$ 10-\$ 100$ mil. & 715 & $2.92^{* * *}$ & 271 & $15.63^{* * *}$ & 33 & $11.73^{* * *}$ \\
\hline $\begin{array}{l}\text { More Than } \$ 100 \text { mil. } \\
\text { Target Status }\end{array}$ & \multicolumn{5}{|c|}{ Target Status } & $17.69^{* * *}$ \\
\hline Priv. & 551 & $6.70^{* * *}$ & & & & \\
\hline Public & 665 & -0.63 & 522 & $15.56^{* * *}$ & 106 & $15.21^{* * *}$ \\
\hline Sub. & 161 & $3.43^{* * *}$ & & & & \\
\hline \multicolumn{7}{|l|}{ Payment Method } \\
\hline Cash Only & 240 & $1.95^{* *}$ & 83 & $21.00^{* * *}$ & 52 & $16.30^{* * *}$ \\
\hline Mixed & 684 & $1.86^{* * *}$ & 198 & $14.69^{* * *}$ & 32 & $15.84^{* * *}$ \\
\hline Stock Only & 453 & 4.59 & 241 & $14.40^{* * *}$ & 22 & $11.74^{* * *}$ \\
\hline \multicolumn{7}{|c|}{ Target Status vs Payment Method } \\
\hline Cash Only Priv. & 75 & $4.46^{* * *}$ & & & & \\
\hline Cash Only Public & 130 & 0.49 & 83 & $21.00^{* * *}$ & 52 & $16.30^{* * *}$ \\
\hline Cash Only Sub. & 35 & 1.96 & & & & \\
\hline Mixed Priv. & 309 & $3.18^{* * *}$ & & & & \\
\hline Mixed Public & 270 & -0.77 & 198 & $14.69^{* * *}$ & 32 & $15.84^{* * *}$ \\
\hline Mixed Sub. & 105 & $4.77^{* *}$ & & & & \\
\hline Stock Only Priv. & 167 & $14.22^{* * *}$ & & & & \\
\hline Stock Only Public & 265 & $-1.05^{*}$ & 241 & $14.40^{* * *}$ & 22 & $11.74^{* * *}$ \\
\hline $\begin{array}{l}\text { Stock Only Sub. } \\
\text { Target Nation }\end{array}$ & 21 & -0.82 & & & & \\
\hline Canada & 1066 & $2.71^{* * *}$ & 522 & $15.56^{* * *}$ & & \\
\hline United States & 311 & $2.100^{* *}$ & & . & 106 & $15.21^{* * *}$ \\
\hline \multicolumn{7}{|l|}{ Form } \\
\hline Merger & 1246 & $2.86^{* * *}$ & 503 & $15.69^{* * *}$ & 103 & $15.55^{* * *}$ \\
\hline Acq. Maj. Int. & 130 & 2.01 & 18 & 12.75 & 3 & 3.66 \\
\hline \multirow{2}{*}{\multicolumn{7}{|c|}{ Related Acquisition }} \\
\hline & & & & & & \\
\hline Related & 614 & 2.25 & 317 & $12.99^{* * *}$ & 49 & $13.44^{* * *}$ \\
\hline Unrelated & 763 & $3.20^{* * *}$ & 205 & $19.53^{* * *}$ & 57 & $16.74^{* * *}$ \\
\hline \multicolumn{7}{|l|}{ Attitude } \\
\hline Friendly & 1350 & $2.85^{* * *}$ & 508 & $15.33^{* * *}$ & 106 & $15.21^{* * *}$ \\
\hline Hostile & 11 & 1.72 & 3 & 35.97 & & \\
\hline Neutral & 16 & -2.53 & 11 & $20.39^{* *}$ & & \\
\hline \multicolumn{7}{|l|}{ Tender Offer } \\
\hline Yes & 212 & -1.19 & 151 & $17.55^{* * *}$ & 33 & $21.59^{* * *}$ \\
\hline No & 1165 & $3.50^{* * *}$ & 371 & $14.75^{* * *}$ & 73 & $12.33^{* * *}$ \\
\hline
\end{tabular}




\section{References}

Akhigbe, A., S. Borde, and A. Whyte (2000). The Sources of Gains to Targets and Their Industry Rivals: Evidence Based on Terminated Merger Proposals. Financial Management 29(4), 101-118.

Akhigbe, A. and A. Martin (2000). Information-Signaling and Competitive Effects of Foreign Acquisitions in the U.S. Journal of Banking and Finance 24, 1307-1321.

Aktas, N., E. de Bodt, and A. Derbaix (2004). Horizontal, Downstream and Upstream Effects of Merger and Acquisition Operations in the Car Industry. Bankers, Markets and Investors 69, 40-49.

Aktas, N., E. de Bodt, and R. Roll (2009). Corporate Serial Acquisitions: An Empirical Test of the Learning Hypothesis. CORE Discussion Papers 2007023.

Amihud, Y., B. Lev, and N. Travlos (1990). Corporate Control and the Choice of Investment Financing: The Case of Corporate Acquisitions. The Journal of Finance 45(2), 603-616.

Andrade, G., M. Mitchell, and E. Stafford (2001). New Evidence and Perspectives on Mergers. Journal of Economic Perspectives 15(2), 103-120.

Asquith, P., R. Bruner, and D. Mullins (1983). The Gains to Bidding Firms from Merger. Journal of Financial Economics 11, 121-139.

Baker, M. and J. Wurgler (2002). Market Timing and Capital Structure. Journal of Finance 57(1), 1-32.

Bange, M. and M. Mazzeo (2004). Board Composition, Board Effectiveness, and the Observed Form of Takeover Bids. Review of Financial Studies 17(4), 1185-1215.

Bauguess, S. and M. Stegemoller (2008). Protective Governance Choices and the Value of Acquisition Activity. Journal of Corporate Finance 14, 550-566.

Ben-Amar, W. and P. André (2006). Separation of Ownership from Control and Acquiring Firm Performance: The Case of Family Ownership in Canada. Journal of Business Finance and Accounting 33(3), 517-543.

Boehmer, E., J. Musumeci, and A. Poulsen (1991). Event-Study Methodology Under Conditions of Event-Induced Variance. Journal of Financial Economics 30(2), 253272.

Bradley, M., A. Desai, and E. Kim (1988). Synergistic Gains from Corporate Acquisitions and their Division Between the Stockholders of Target and Acquiring Firms. Journal of Financial Economics 21, 3-40. 
Brown, D. and M. Ryngaert (1991). The Mode of Acquisition in Takeovers: Taxes and Asymmetric Information. The Journal of Finance 46(2), 653-669.

Brown, S. and J. Warner (1985). Usual Daily Stock of Event Studies. Journal of Financial Economics 14, 3-31.

Chang, S. (1998). Takeover of Privately Held Targets, Methods of Payment and Bidder Returns. The Journal of Finance 53(2), 773-784.

Chatterjee, S. (1986). Types of Synergy and Economic Value: The Impact of Acquisitions on Merging and Rival Firms. Strategic Management Journal 7(2), 119-139.

Doukas, J. and N. Travlos (1988). The Effect of Corporate Multinationalism on Shareholders' Wealth: Evidence from International Acquisitions. The Journal of Finance 43(5), 1161-1175.

Dutta, S. and V. Jog (2009). The Long-Term Performance of Acquiring Firms: A Re-Examination of an Anomaly. Journal of Banking and Finance 33, 1400-1412.

Eckbo, E. (1983). Horizontal Mergers, Collusion, and Stockholders Wealth. Journal of Financial Economics 11, 241-273.

Eckbo, E. and K. Thorburn (2000). Gains to Bidder Firms Revisited: Domestic and Foreign Acquisitions in Canada. Journal of Financial and Quantitative Analysis, $35(1), 1-25$.

Eckbo, E. and P. Wier (1985). Antimerger Policy Under the Hart-Scott-Rodino Act: A Reexamination of the Market Power Hypothesis. Journal of Law and Economics 28(1), 119-149.

Eun, S., R. Kolodny, and C. Scheraga (1996). Cross-Border Acquisitions and Shareholder Wealth: Tests of the Synergy and Internalization Hypotheses. Journal of Banking and Finance 20, 1559-1582.

Faccio, M., J. McConnell, and D. Stolin (2006). Returns to Acquirers of Listed and Unlisted Targets. Journal of Financial and Quantitative Analysis 41(1), 197-220.

Fama, E., L. Fisher, M. Jensen, and R. Roll (1969). The Adjustment of Stock Prices to New Information. International Economic Review 10, 1-21.

Fee, C. and S. Thomas (2004). Sources of Gains in Horizontal Mergers: Evidence from Customer, Supplier, and Rival Firms. Journal of Financial Economics 74, 423-460.

Fuller, K., J. Netter, and M. Stegemoller (2002). What Do Returns to Acquiring Firms Tell Us? Evidence From Firms That Make Many Acquisitions. The Journal of Finance 57(4), 1763-1794. 
Glais, M. (1993). Analyse Typologique des Ententes Illicites Soumises à l'Appréciation des Autorités Concurrentielles Françaises et Communautaires. Revue d'Economie Industrielle 63(1), 45-83.

Goldman, E. and J. Qian (2005). Optimal Toeholds in Takeover Contests. Journal of Financial Economics 77, 321-346.

Haltiwanger, J. and J. Harrington (1991). The Impact of Cyclical Demand Movements on Collusion Behavior. RAND Journal of Economics 22(1), 89-106.

Hansen, R. (1987). A Theory for the Choice of Exchange Medium in Mergers and Acquisitions. Journal of Business 60, 75-95.

Hansen, R. and J. Lott (1996). Externalities and Corporate Objectives in a World with Diversified Shareholders/Consumers. Journal of Financial and Quantitative Analysis 31, 43-68.

Hay, G. and D. Kelley (1974). An Empirical Survey of Price Fixing Conspiracies. Journal of Law and Economics 17(1), 13-38.

Huang, Y. and R. Walkling (1987). Target Abnormal Returns Associated with Acquisition Announcements: Payment, Acquisition Form, and Managerial Resistance. Journal of Financial Economics 19, 329-349.

Jarrell, G. and M. Bradley (1980). The Economic Effects of Federal and State Regulations of Cash Tender Offers. Journal of Law and Economics 23(2), 371-407.

Jarrell, G. and A. Poulsen (1989). The Returns to Acquiring Firms in Tender Offers: Evidence from 3 Decades. Financial Management 18(3), 12-19.

Jensen, M. and R. Ruback (1983). The Market for Corporate Control: The Scientific Evidence. Journal of Financial Economics 11, 5-50.

Kahle, K. and R. Walkling (1996). The Impact of Industry Classifications on Financial Research. Journal of Financial and Quantitative Analysis 31, 309-335.

Kau, J., S. Linck, and P. Rubin (2008). Do Managers Listen to the Market? Journal of Corporate Finance 14(4), 347-362.

Kohers, N. and T. Kohers (2000). The Value Creation Potential of High-Tech Mergers. Financial Analysts Journal 56(3), 40-50.

Mikkelson, W. and M. Partch (1989). Managers' Voting Rights and Corporate Control. Journal of Financial Economics 25, 263-290. 
Moeller, S. and F. Schlingeman (2005). Global Diversification and Bidder Gains: A Comparison Between Cross-Border and Domestic Acquisitions. Journal of Banking and Finance 29, 533-564.

Moeller, S., F. Schlingeman, and R. Stulz (2004). Firm Size and the Gains from Acquisitions. Journal of Financial Economics 73, 201-228.

Morck, R., A. Shleifer, and R. Vishny (1990). Do Managerial Motives Drive Bad Acquisitions? The Journal of Finance 45(1), 31-48.

Mulherin, J. and A. Boone (2000). Comparing Acquisitions and Divestitures. Journal of Corporate Finance 6(2), 117-139.

Myers, S. and N. Majluf (1984). Corporate Financing and Investment Decisions When Firms Have Information that Investors Do Not Have. Journal of Financial Economics 13, 187-221.

Officer, M., A. Poulsen, and M. Stegemoller (2009). Target-Firm Information Asymmetry and Acquirer Returns. Review of Finance 13(3), 467-493.

Ravenscraft, D. and F. Scherer (1987). Mergers, Sell-Offs, and Economic Efficiency. Washington, DC: The Brookings Institution.

Salant, S., S. Switzer, and R. Reynolds (1983). Losses from Horizontal Merger: The Effects of an Exogenous Change in Industry Structure on Cournot-Nash Equilibrium. Quarterly Journal of Economics 98(2), 185-199.

Schwert (1996). Markup Pricing in Mergers and Acquisitions. Journal of Financial Economics 41, 153-192.

Schwert, W. (2000). Hostility in Takeovers: In the Eye of Beholder? The Journal of Finance 55, 2599-2640.

Servaes, H. (1991). Tobin's Q and the Gains from Takeovers. The Journal of Finance 46(1), 409-419.

Shleifer, A. and R. Vishny (1986). Large Shareholders and Corporate Control. The Journal of Political Economy 94(3), 461-488.

Slade, M. (1989). Price Wars in Price-Setting Supergames. Economica 56(223), 295310.

Song, M. and R. Walkling (1993). The Impact of Managerial Ownership on Acquisition Attempts and Target Shareholder Wealth. Journal of Financial and Quantitative Analysis 28(4), 439-457. 
Song, M. and R. Walkling (2000). Abnormal Returns to Rivals of Acquisition Targets: A Test of the 'Acquisition Probability Hypothesis'. Journal of Financial Economics 55, 143-171.

Spence, M. (1978). Tacit Co-Ordination and Imperfect Information. The Canadian Journal of Economics 11(3), 490-505.

Stigler, G. (1950). Monopoly and Oligopoly by Merger. American Economic Review $40(2), 23-34$.

Stillman, R. (1983). Examining Antitrust Policy Towards Horizontal Mergers. Journal of Financial Economics 11, 225-240.

Travlos, N. (1987). Corporate Takeover Bids, Method of Payment, and Bidding Firms' Stock Return. The Journal of Finance 42(4), 943-963.

Walkling, R. (1985). Predicting Tender Offer Success: A Logistic Analysis. Journal of Financial Quantitative Analysis 20(4), 461-478.

Yuce, A. and A. Ng (2005). Effects of Private and Public Canadian Mergers. Canadian Journal of Administrative Sciences 22(2), 111-124. 